\title{
Production and evaluation of yoghurt flavoured with fresh and dried cashew (Anacardium occidentale) apple pulp
}

\author{
"Mbaeyi-Nwaoha, I.E. and Iwezor-Godwin, L.C. \\ Department of Food Science and Technology, University of Nigeria, Nsukka (www.unn.edu.ng) \\ *Corresponding author Email: miphie2003@yahoo.co.uk or ifeoma.mbaevi-nwaoha@unn.edu.ng
}

\section{ABSTRACT}

\begin{abstract}
Yoghurt was flavoured by blending with 10, 20, 30, 40 and $50 \%$ fresh and dried cashew (Anacardium occidentale) apple pulp (FCP and DCP) respectively. The cashew flavoured yoghurt samples were subjected to physico-chemical ( $\mathrm{pH}$, titrable acidity and total solids), microbiological and sensory evaluation using standard procedures. Results showed that the moisture content of the flavoured samples decreased with increased concentration of the fresh and dried cashew pulp respectively. The protein content ranged 3.44 to $4.43 \%$ for the fresh cashew pulp flavoured yoghurt while the yoghurt flavoured with dried cashew pulp was $5.31 \%$ and the protein content for the plain yoghurt (PY) was 5.53. The fat content for the fresh cashew apple flavoured yoghurt ranged 0.29 to $0.64 \%$ while the yoghurt flavoured with dried cashew apple pulp was $0.68 \%$. However, the carbohydrate and vitamin C increased with increased level of both fresh and dried cashew pulp apple. Potassium and calcium contents of the samples decreased with increased concentration of the dried and fresh cashew pulp compared to the plain yoghurt. There were significant $(p<0.05)$ differences in the micronutrient between the cashew apple pulp flavoured yoghurt samples and the plain yoghurt. It was also observed that the $\mathrm{pH}$ ranged from $\mathbf{4 . 4 0}$ to $4.65 \%$ for the yoghurt flavoured with fresh cashew apple pulp while the $\mathrm{pH}$ for the dried cashew apple pulp was $5.45 \%$. The titrable acidity for the plain yoghurt was $0.55 \%$ while for the fresh and dried cashew pulp flavoured yoghurt was 0.42 to $0.52 \%$ and $0.36 \%$ respectively. There was an inverse relationship between the $\mathrm{pH}$ and the titrable acidity. The lactic acid bacteria count was inversely proportional to the concentration of the cashew pulp. There was a decrease in the total viable count of the formulated yoghurt samples with the exception of the sample containing $10 \%$ DCP. The total viable count ranged from $1.3 \times 10^{4}$ in sample PY + FCP $(60: 40)$ to $1.0 \times 10^{5} \mathrm{cfu} / \mathrm{ml}$ in sample containing $10 \%$ DCP. However, the values for lactic acid bacteria varied from $1.5 \times 10^{4}-2.7 \times 10^{5} \mathrm{cfu} / \mathrm{ml}$. The most acceptable flavoured yoghurt by the panelists contained $10 \%$ fresh and dried cashew apple pulps, respectively.
\end{abstract}

Key words: Fresh/dried cashew apple pulps, Flavoured yoghurt, Microbiological properties, Physico-chemical composition.

\section{INTRODUCTION}

The milk of cow is nutritive and it can be processed into products like cheese, butter and yoghurt and some dairy products made from cow's milk have been reported (Adegoke et al., 1992). Yoghurt is a semi-solid fermented milk product that has been given different names and forms (Tamine and Robinson, 2007). Yoghurt is a food staple that can be enjoyed in many different ways. Yoghurt is a fermented coagulated milk product that is obtained through an anaerobic fermentation of lactose in milk by relevant microorganisms which are classified as 
Nwaoha et al. 235

probiotic (Tull, 1996). Yoghurt is produced from fermented milk, which is rich in sugars (lactose). An environment rich in sugars is an environment that microbes could thrive in. Since yoghurt is produced from milk which contains a reasonable amount of live cultures (bacteria), the presence of other bacteria could lead to production of undesirable product with low shelf life. The benefits of having a fermented product are that few other potentially harmful microorganisms could grow in yoghurts acidic environment. Thus, yoghurt could be stored safely longer than milk. Therefore, the production of yoghurt is a way of preserving fresh milk. The fermentation of the lactic acid in milk occurs as a result of the action of the lactic acid bacteria, Lactobacillus bulgaricus and Streptococcus thermophilus. These strains secrete an enzyme called galactosidase that allows them to pre-digest part of the lactose (the sugar in milk). This is why generally people with lactose intolerance can easily digest yoghurt. Yoghurt generally contains at least $3.25 \%$ milk fat and $8.25 \%$ solids non fat. Yoghurt can be low fat $(0.5-2 \%)$ or non fat (less than $0.5 \%$ milk fat) which is more preferred because of health claims.

Yoghurt is one of the best known foods that contain probiotics, that are living micro-organism upon which ingestion in sufficient amount exerts beneficial effects on the normal microbial population of the gastrointestinal tract (Bourlioux et al., 2003). The aroma, taste and body of yoghurt and other cultured dairy products can vary depending on the type of milk and culture, amount of milk fat and non fat milk solids, fermentation process and temperature used. It is traditionally prepared by fortifying whole or skimmed milk by evaporation or addition of skim milk powder, heating to $85-95{ }^{\circ} \mathrm{C}$ for $10-30$ minutes and inoculating with lactic acid bacteria and incubating at $42-45{ }^{\circ} \mathrm{C}$.

Many consumers associate yoghurt with good health. The popularity of yoghurt as a food component has been linked to its sensory characteristics (Routray and Mishra, 2011). Along these, the flavour of yoghurt has played an important role in increasing its consumers demand. Yoghurt is an excellent source of calcium and high in protein quality but it contains very little iron which is common among all dairy products (Blanc, 1981). To modify certain properties of yoghurt ingredients like fruits are added to the fermentation media to enhance the organoleptic and nutritional properties, such as strawberry and vanilla, which have been used to produce standard yoghurt. Furthermore, most fruits are seasonal and highly perishable. These fruits therefore undergo post-harvest losses especially during harvesting, storage, poor transportation, pest attack and spoilage. To avoid these losses, most of this fruits could be used to flavour yoghurt and act as a nutritional additive.

However, there are some underutilized tropical fruits that could be used to flavour yoghurt for instance; cashew pulp or cashew apple (Anacardium occidentale). Cashew is a species of fruit that produces the cashew nut. However, despite its appearance, cashews are not actually nuts; they are seeds from their fruits. The fruit is unusual because shortly before the seeds mature the pedicle (stalk) enlarges and becomes sweet cashew apple. Fruit that appears as though one of its ends has been forcibly sunk into the end of a pear shaped, swollen stem called cashew apple which is about three times as large as the nut and usually yellow to intense red. The cashew apple is used locally in beverages, jams and jellies. Cashew apple is rich in vitamin $C$ and has an anti scurvy effect. Cashew apples possess anti-bacterial properties and have been proven to be effective in treating stomach ulcers. Cashew extract contains anacardic acid, which is an antioxidant and has been shown to limit the pigmentation effects of aging and to eradicate the cancer cells.

Full of vitamins and minerals and contain disease fighting anti bacterial agents, cashew apple has been rated as one of the leading indigenous fruits and huge amounts are seen in local markets during harvest seasons in several countries of South America and Africa (Akinwale, 2000). The cashew apples are highly perishable or susceptible to spoilage. To prevent this spoilage and to improve on the use of the nutritive properties of the fruit, its use as a nutritional additive in the production of yoghurt would increase and/or add to the nutritional quality of the product by providing essential vitamins and minerals. It would also contribute to the taste, increase micronutrient requirements of the consumer, also increase options for consumers, help in marketing yoghurt and retaining consumer interest even with changing food habits.

The annual production of cashew apple is about 5.2 million tonnes most of which is left to rot in the field under the trees for lack of adequate storage and processing facilities, thus this becomes a waste, pollutes soil, harbor insects and constitute serious environmental problems. The cashew apple is quite perishable, it will rot within 24 hours of falling or detached from a tree. Therefore, there is a need to find a wider use for cashew apples.

Meanwhile, the studies carried out in at Cocoa Research Institute of Nigeria (CRIN) revealed that the present consumption of cashew apple either in raw or processed form is about $10 \%$ of production (Oduwole et al., 2001). As such, its use as a flavourant in the production of yoghurt which is a very popular and most widely consumed fermented dairy product, would increase the number of consumers that derive from the wide benefits of cashew apple and help to prevent these post-harvest losses. Consuming yoghurt flavoured with fruits increases the nutritional content and also increases the health benefits. Thus, the use of cashew apple as a flavourant not only adds to the variety of flavoured yoghurt, it provides consumers with choices and help to 
Fresh cashew apple

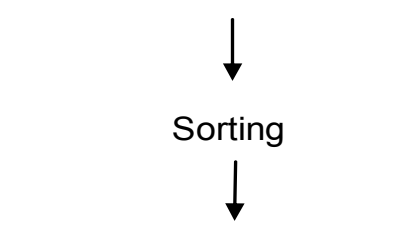

Twisting to remove nut

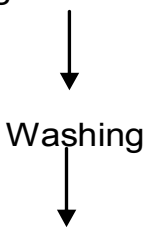

Blending (Massterchef blender, model no: MC - BL6731J)

Pasteurization $\left(85^{\circ} \mathrm{C}\right.$ for 3 minutes $)$

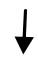

Cooling

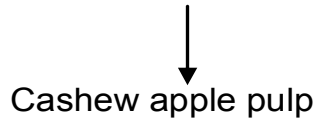

Figure 1. Processing of fresh cashew apple pulp Source: Mbaeyi-Nwaoha and Ekere (2014)

improve the organoleptic and health benefits of the yoghurt.

The broad objective of the study was to produce and evaluate yoghurt flavoured with cashew apple (fresh and dried cashew pulp) for sensory, microbial, proximate, physicochemical and micronutrient composition.

\section{MATERIALS AND METHODS}

\section{Source of raw materials}

The cashew (yellow variety), skimmed milk, starter culture (yoghurmet), sugar were obtained from Ogige main market in Nsukka local Government area of Enugu state, Nigeria.

\section{Sample preparation}

\section{Processing of cashew pulp}

The cashew fruit $(1 \mathrm{Kg})$ was processed first by sorting to remove the bad ones after which they were twisted to remove the nut, they were washed and then blended using a food blender (Masterchef blender, model no: MC - BL6731J). The pulp was then pasteurized for $85^{\circ} \mathrm{C}$ for 3 minutes. It was then cooled. The processing of cashew pulp production is shown in Figure 1.

\section{Production of dried cashew pulp}

Two kilogrammes of ripe mature cashew fruits (yellow variety) had the nuts first detached from the apple manually and the apples were sorted, weighed and washed in sodium metabisulphate solution $(350 \mathrm{ppm})$ to remove contaminants from them. Cashew apples were then cut into small pieces with stainless steel knife and placed in a stainless tray for drying process. The samples were oven dried at $65{ }^{\circ} \mathrm{C}$ for 12 hours until the final moisture attained $7.0 \%$ Ogunjobi and Ogunwolu (2010) as shown in Figure 2.

\section{Production of cashew flavoured yoghurt}

The cashew apple fruit flavoured yoghurt was processed as described by Ihekoronye (1999). The raw materials 
Nwaoha et al. 237

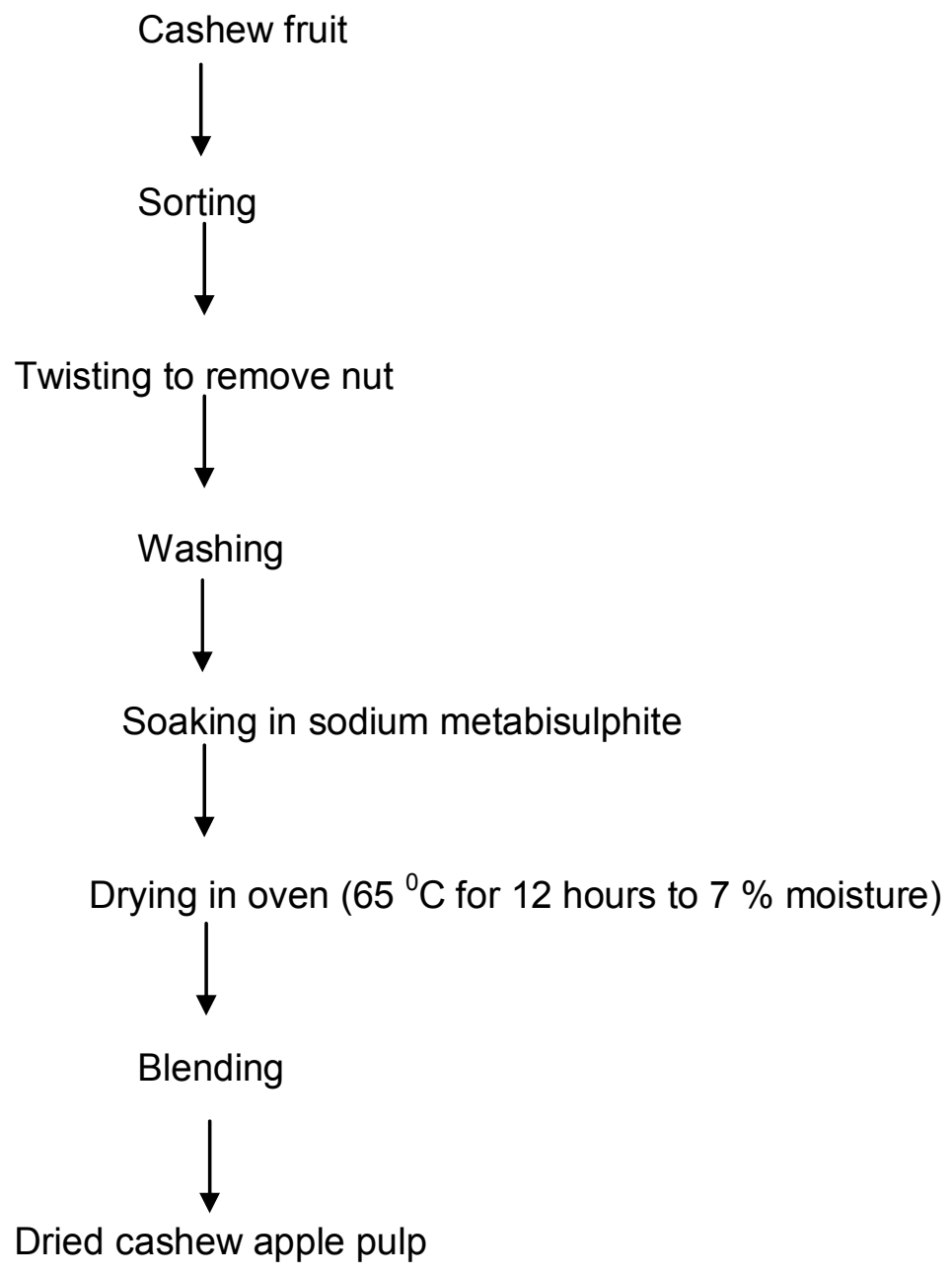

Figure 2. Processing of dried cashew apple pulp Source: Ogunjobi and Ogunwolu (2010).

(skimmed milk, and sugar were appropriately weighed and mixed with water. The mixed product was then homogenized to obtain a creamy and uniform product. Pasteurization was then carried out at $82-85{ }^{\circ} \mathrm{C}$ for 30 minutes as shown in Figure 3 to destroy the undesirable microorganism (pathogenic and spoilage microorganisms) in the raw materials to provide a flavour enrichment free from competition for the growth of starter culture. The yoghurt mix was then dispatched into different ratios into the jars. The product was then cooled to temperature of $43-46{ }^{\circ} \mathrm{C}$ which is the ideal growth temperature of the starter culture. The cashew apple pulp/ dried pulp (already weighed) was added and the starter inoculated. Fermentation was then carried out for 18 hours at $42 \pm 2{ }^{\circ} \mathrm{C}$ after which yoghurt was set in retort bottles following stirring. Table 1 shows the blending ratios of cashew apple pulp flavoured yoghurt

\section{Sample analysis}

The following proximate analysis were carried out on the formulated cashew apple flavoured yoghurt

\section{Determination of moisture content of the formulated cashew apple flavoured yoghurt}

The moisture content of the samples was determined using hot oven method of AOAC (2010). Two millimeters $(2 \mathrm{ml})$ of each sample was put into a washed dried crucible dish and placed in a Phoenix oven (Preiser model, New York, USA) at a temperature of $70-80{ }^{\circ} \mathrm{C}$ for 2 hours and $100-105{ }^{\circ} \mathrm{C}$ until the weight is constant. The samples were cooled in a desiccator and weighed. The weight loss was obtained as the moisture content was calculated as; 
Skimmed milk

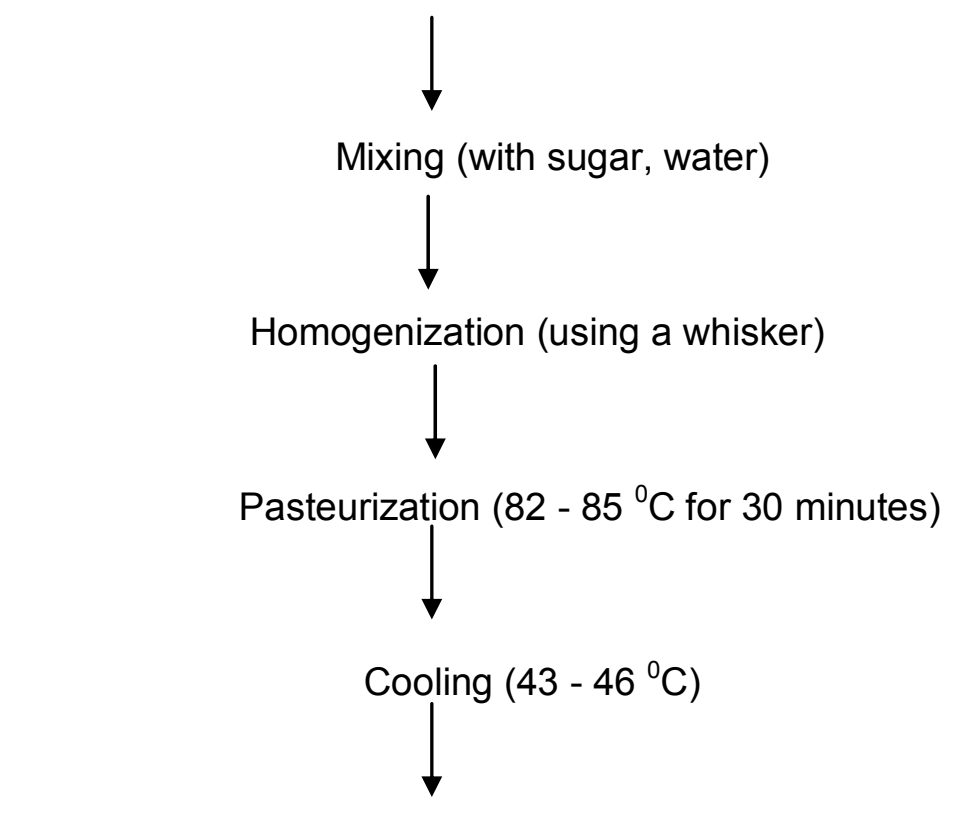

Addition of processed cashew (fresh / dried) apple fruit pulp

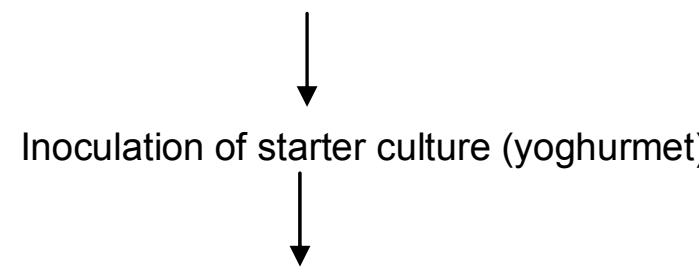

Fermentation (42 $\pm 2{ }^{\circ} \mathrm{C}$ for 18 hours)

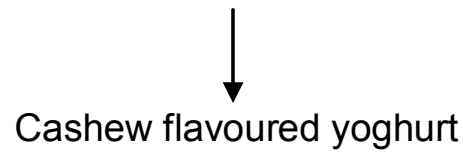

Figure 3. Production of flavoured yoghurt with fresh cashew apple pulp/ dried pulp Source: Ihekoronye (1999)

$\%$ Moisture content $=\frac{W_{2}-W_{3}}{W_{2}-W_{1}} \times \frac{100}{1}$

Where; $W_{1}=$ initial weight of empty crucible; $W_{2}=$ weight of crucible + sample before drying; $W_{3}=$ final weight of crucible $=$ sample after drying.

\section{Determination of crude protein content of the formulated cashew apple flavoured yoghurt}

The crude protein of the samples was determined by the semi-micro Kjeldahl technique described by AOAC (2010). A millimeter (1.0) of the sample was put into a Kjeldahl flask. Three milliliter $(3 \mathrm{ml})$ anhydrous sodium sulphate and one $(1 \mathrm{~g})$ of hydrated copper sulphate (catalyst) were added into the flask. Then, $20 \mathrm{ml}$ of concentrated tetraoxosulphate $(\mathrm{VI})$ acid $\left(\mathrm{H}_{2} \mathrm{SO}_{4}\right)$ was added to digest the sample. The clear solution was then cooled and made up to $100 \mathrm{ml}$ with distilled water and a digest of $5 \mathrm{ml}$ was collected for distillation. Also, $5 \mathrm{ml}$ of $60 \%$ sodium hydroxide $(\mathrm{NaOH})$ was put into the distillation flask and distillation was allowed to take place for some minutes. The ammonia distilled off was absorbed by boric acid indicator and this was titrated with $0.01 \mathrm{M}$ hydrochloric acid $(\mathrm{HCl})$. The titre value of the end point at which the colour changed from green to pink was taken. The crude protein was calculated as:

$\%$ Crude protein $=\underline{0.0001401 \times T 100 \times 6.25}$ $\mathrm{W} \times 5$ 
Nwaoha et al. 239

Table 1.Proportion for blending of cashew apple pulp (fresh and dried) flavoured yoghurt

\begin{tabular}{lll}
\hline Sample & Plain yoghurt (\%) & Fresh cashew pulp (\%) \\
\hline PY + CP (100:0) & 100 & 0 \\
PY + FCP (90:10) & 90 & 10 \\
PY + FCP $(80: 20)$ & 80 & 20 \\
PY + FCP (70:30) & 70 & 30 \\
PY + FCP (60:40) & 60 & 40 \\
PY + FCP (50:50) & 50 & 50 \\
& & Dried cashew pulp (\%) \\
PY + DCP $(90: 10)$ & 90 & 10 \\
PY + DCP (80:20) & 80 & 20 \\
PY + DCP (70:30) & 70 & 30 \\
PY + DCP (60:40) & 60 & 40 \\
PY + DCP (50:50) & 50 & 50 \\
\hline
\end{tabular}

Where; $\mathrm{T}=$ titre value; $\mathrm{W}=$ weight of sample dried

\section{Determination of crude fiber content of the formulated cashew apple flavoured yoghurt}

Crude fiber was done using the method Kirk and Sawyer (1991). $2 \mathrm{ml}$ of the sample was hydrolyzed in beaker with $229 \mathrm{ml}$ of $1.25 \%$ tetraoxosulphate $(\mathrm{VI})$ acid $\left(\mathrm{H}_{2} \mathrm{SO}_{4}\right)$ and boiled for 30 minutes. The mixture was filtered, washed with hot water and boiled again for 30 minutes with 200 $\mathrm{ml}$ of $1.25 \%$ of $\mathrm{NaOH}$ and then with hot distilled water for several times. The residue was put into weighed crucible and dried at $100{ }^{\circ} \mathrm{C}$ for 3 hours in an air oven, after drying the sample was cooled, weighed and then transferred into a muffle furnace for burning a $500{ }^{\circ} \mathrm{C}$ for 5 hours. The loss in weight was taken and percentage crude fiber was calculated as follows

Percentage crude fiber $=$

Loss in weight $(\mathrm{g})$ after ignition $\times 100$

Weight of the original sample

\section{Determination of ash content of the formulated cashew apple flavoured yoghurt}

The ash content of the sample was determined by the method recommended by AOAC (2010). A silica dish was heated to about $60{ }^{\circ} \mathrm{C}$, cooled in a desiccator and weighed. Five milliliters $(5 \mathrm{ml})$ of the sample was put into the silica dish and transferred to the furnace. The temperature of the furnace was then allowed to reach $525^{\circ} \mathrm{C}$ after placing the dish in it. The temperature was maintained until whitish colour was obtained indicating that all the organic matter content of the sample has been destroyed. The dish was then brought out from the furnace and cooled in the desiccator and re- weighed. The percentage ash was then calculated.

\section{Determination of crude fat content of the formulated cashew apple flavoured yoghurt}

The crude fat was determined using AOAC (2010) method. Then, 2 milliliters of each of the samples were loosely wrapped with a filter paper and put into the thimble which was fitted to a clean round bottom flask, which has been cleaned, dried and weighed. The flask contained $120 \mathrm{ml}$ of petroleum ether (B.P $=40-60{ }^{\circ} \mathrm{C}$ ). The sample was heated with a heating mantle and allowed to reflux for 5 hours. The heating was then stopped and the thimbles with the samples kept and later weighed. The difference in weight was received as mass of fat and is expressed is percentage of the sample.

$\%$ Fat Content $=\frac{W_{2}-W_{1}}{W_{3}} \quad x \quad \frac{100}{1}$

Where; $W_{1} \quad=$ Weight of the empty extraction flask; $W_{2}=$ Weight of the flask and oil extracted; $W_{3}=$ Weight of the sample

Determination of carbohydrate content of the formulated cashew apple flavoured yoghurt

Carbohydrate content was determined by difference. It was done by subtracting the value of other food component (moisture, ash, fiber and protein) from 100 as described by Oyenuga (1968)

Percentage carbohydrate $=100-(\%$ fat $+\%$ protein $+\%$ moisture $+\%$ ash $+\%$ crude fiber)

\section{Physico-chemical analysis of the formulated cashew apple flavoured yoghurt Determination of $\mathrm{pH}$}

The $\mathrm{pH}$ was done using a $\mathrm{pH}$ meter described by AOAC (2010). The electrode was dipped in already weighed 5 $\mathrm{ml}$ of the flavoured yoghurt and the $\mathrm{pH}$ was recorded 


\section{Determination of titrable acidity}

The titrable acidity was determined by the method described by AOAC (2010). Then, $5 \mathrm{ml}$ of the sample was taken and titrated with $0.1 \mathrm{~N}$ alkali $(\mathrm{NaOH})$ using 0.5 $\mathrm{ml}$ phenolphthalein as indicator. Titration continued until there was a change in colour to pink end point. The titration was repeated to get the average value.

$\%$ Titrable acidity $=\mathrm{M}(\mathrm{NaOH}) \times \mathrm{N}(\mathrm{NaOH}) \times 0.09 \times 100$

$$
\text { Volume of sample }
$$

\section{Determination of total solid content}

This was determined by drying $5 \mathrm{ml}$ of the sample to constant weight in a hot air oven at $130{ }^{\circ} \mathrm{C}$. The total solid content was obtained as percentage (\%) total solids (AOAC, 2010).

$\%$ Total solids $=\frac{\text { Weight of dried sample } \times 100}{\text { Weight of sample }}$

Micronutrient determination of the formulated cashew apple flavoured yoghurt

Determination of vitamin C content

The ascorbic acid content was determined using the method described by Osborne and Voogt (1978). Two milliliters $(2 \mathrm{ml})$ of each of the samples were weighed out and $100 \mathrm{ml}$ of distilled water was added to it. It was then filtered to get a clear solution. A $10 \mathrm{ml}$ volume of the solution was pipetted into a small flask containing $2.5 \mathrm{ml}$ acetone. The solution was then titrated with indo-phenol solution (2, 6 - dichloro-phenol indophenol) to a faint pink colour which persists for 15 seconds. The vitamin C content was calculated as:

Vitamin C (mg / $100 \mathrm{ml}$ of sample) $=20 \times \mathrm{V} \times \mathrm{C}$

Where $\mathrm{V}=$ Indophenol soulution in titration $(\mathrm{ml}) ; \mathrm{C}=\mathrm{Mg}$ (milligram) vitamin $\mathrm{C} / \mathrm{ml}$ indophenols ; $20=$ Dilution factor

\section{Determination of calcium content}

It was determined by titration method according to Kirk and Sawyer (1991). Then, two millimeters $(2 \mathrm{ml})$ of the ashed sample was diluted with $3 \mathrm{ml}$ of distilled water and $1 \mathrm{ml}$ of $50 \%$ ammonium oxalate. One drop of methyl red indicator was made alkaline with ammonia drops and drops of glacial acetic acid until colour changes to pink. It was stood for 4 hours and centrifuged for 5 minutes, followed by decantation of the supernatant. A $1 \mathrm{ml}$ hydrogen sulphate was added to the residue which was diluted with $4 \mathrm{ml}$ of distilled water. The solution was boiled and titrated with $0.02 \mathrm{~N}$ potassium permanganate.

\section{Determination of potassium content}

Phosphorous content was determined by the method described by Pearson (1976). Five millimeters $(5 \mathrm{ml})$ of the sample was ashed and the ash transferred to $500 \mathrm{ml}$ beaker and dissolved with $100 \mathrm{ml}$ of water. Then, $10 \mathrm{ml}$ volume of concentrated hydrochloric acid was added and the mixture was boiled for several minutes, cooled and diluted with water to $500 \mathrm{ml}$, and filtered. The solution was further diluted to a final concentration of approximately $15 \mathrm{mg} / \mathrm{L}$ potassium oxide $\left(\mathrm{K}_{2} \mathrm{O}\right)$. Freshly prepared standard potassium solution containing 10, 12, 14, 16, 18 and $20 \mathrm{mg} / \mathrm{L}\left(\mathrm{K}_{2} \mathrm{O}\right)$ was also prepared. Absorbance readings were taken with atomic spectrophotometer ( $\mathrm{Hi}$ Tech Japan) with a hollow cathode lamp of current $(5 \mathrm{~mA})$, slit width $(0.7 \mathrm{~nm})$ and $\lambda$ $(7.66 .5 \mathrm{~nm})$

\section{Microbial analysis of the formulated cashew apple flavoured yoghurt}

\section{Determination of total viable count}

One Ringer tablet was dissolved in distilled water (500 $\mathrm{ml}$ ). The clear solution formed was sterilized by autoclaving for 15 minutes at $121^{\circ} \mathrm{C}$ and $15 \mathrm{lb}$ pressure. The Ringer solution was allowed to cool completely to a temperature of about $28 \pm 2{ }^{\circ} \mathrm{C}$. The total viable count was carried out using Prescott et al. (2005). Using of sample and sterilized quarter strength ringer solution as diluents, $1 \mathrm{ml}$ of the sample and $9 \mathrm{ml}$ ringer solution was used for serial dilutions $\left(10^{-1}, 10^{-2}, 10^{-3}\right)$. The diluted sample was pipetted into a marked petri dish, swirled to mix and incubated at the temperature of about $37{ }^{\circ} \mathrm{C}$ for 24 hours. After incubation, the number of colonies was counted and represented as colony forming unit per millimeter (cfu/ml).

\section{Determination of lactic acid bacteria (LAB)}

The lactic acid bacteria (LAB) count of the formulated yoghurt was determined using deMan Rogosa Sharpe (MRS) agar (Oxoid CM 361) according to Harrigan and McCance (1976). Samples were serially diluted in duplicates using the surface pour plate method. The plates were incubated in an anaerobic jar under anaerobic conditions at $37{ }^{\circ} \mathrm{C}$ for 48 hours and then counted.

Sensory evaluation of the formulated cashew apple pulp flavoured yoghurt

A total of 20 semi-trained panelists consisting of students of Department of Food Science and Technology, 
Table 2. Sensory properties of yoghurt flavoured with fresh and dried cashew pulp

\begin{tabular}{|c|c|c|c|c|c|c|c|}
\hline Sample & Colour & Aroma & Taste & Aftertaste & sistency & Mouthfeel & $\begin{array}{l}\text { Overall } \\
\text { Acceptability }\end{array}$ \\
\hline$P Y+C P(100: 0)$ & $8.20^{\dagger} \pm 0.89$ & $6.15^{\mathrm{bc}} \pm 1.98$ & $6.55^{\mathrm{c}} \pm 1.47$ & $5.80^{c} \pm 1.51$ & $6.80^{d} \pm 1.82$ & $6.70^{c} \pm 1.63$ & $6.95^{d} \pm 1.85$ \\
\hline$P Y+F C P(90: 10)$ & $6.95^{\mathrm{e}} \pm 1.01$ & $6.65^{c} \pm 0.81$ & $5.40^{\mathrm{cd}} \pm 1.76$ & $5.20^{a b c} \pm 1.85$ & $5.70^{d} \pm 1.56$ & $5.70^{\mathrm{bc}} \pm 2.08$ & $6.40^{\mathrm{cd}} \pm 1.47$ \\
\hline$P Y+F C P(80: 20)$ & $6.20^{\mathrm{de}} \pm 1.32$ & $5.10^{\mathrm{ab}} \pm 1.55$ & $5.10^{\mathrm{bc}} \pm 1.55$ & $4.00^{a} \pm 1.21$ & $5.65^{\mathrm{bcd}} \pm 1.69$ & $4.90^{\mathrm{ab}} \pm 1.97$ & $5.40^{b c} \pm 0.97$ \\
\hline$P Y+F C P(70: 30)$ & $5.35^{\mathrm{cd}} \pm 1.50$ & $4.80^{a} \pm 1.40$ & $4.65^{\mathrm{abc}} \pm 1.66$ & $4.65^{\mathrm{abc}} \pm 1.95$ & $5.10^{a b c} \pm 1.20$ & $4.85^{\mathrm{ab}} \pm 1.50$ & $5.20^{\mathrm{ab}} \pm 0.97$ \\
\hline$P Y+F C P(60: 40)$ & $4.35^{\mathrm{bc}} \pm 2.18$ & $5.05^{\mathrm{ab}} \pm 1.99$ & $4.45^{a b c} \pm 2.16$ & $4.60^{\mathrm{abc}} \pm 1.60$ & $4.75^{\mathrm{abc}} \pm 1.37$ & $4.85^{\mathrm{ab}} \pm 2.05$ & $5.45^{b c} \pm 1.23$ \\
\hline$P Y+F C P(50: 50)$ & $4.40^{\mathrm{bc}} \pm 1.70$ & $5.30^{\mathrm{ab}} \pm 1.95$ & $3.80^{\mathrm{ab}} \pm 1.88$ & $4.10^{a b} \pm 1.68$ & $5.55^{\mathrm{bcd}} \pm 1.47$ & $4.75^{a} \pm 2.40$ & $4.90^{\mathrm{ab}} \pm 1.23$ \\
\hline$P Y+D C P(90: 10)$ & $5.40^{\mathrm{cd}} \pm 2.10$ & $4.95^{\mathrm{ab}} \pm 2.09$ & $5.10^{b c} \pm 1.45$ & $4.95^{a b c} \pm 1.76$ & $5.05^{a b c} \pm 1.82$ & $4.30^{a b} \pm 1.71$ & $5.35^{\mathrm{ab}} \pm 1.50$ \\
\hline$P Y+D C P(80: 20)$ & $4.70^{c} \pm 2.20$ & $4.20^{a} \pm 2.31$ & $4.20^{a b c} \pm 1.93$ & $3.95^{a} \pm 2.01$ & $4.10^{a} \pm 2.27$ & $3.75^{\mathrm{ab}} \pm 2.07$ & $4.50^{\mathrm{ab}} \pm 1.82$ \\
\hline PY + DCP $(70: 30)$ & $3.15^{\mathrm{ab}} \pm 1.87$ & $4.25^{a} \pm 1.77$ & $3.65^{a} \pm 1.63$ & $5.50^{c} \pm 2.33$ & $4.20^{a} \pm 2.33$ & $4.10^{a} \pm 2.40$ & $4.15^{a} \pm 1.79$ \\
\hline$P Y+D C P(60: 40)$ & $4.20^{\mathrm{abc}} \pm 2.50$ & $4.35^{a} \pm 2.10$ & $4.05^{a b c} \pm 2.23$ & $5.20^{a b c} \pm 2.14$ & $4.45^{\mathrm{ab}} \pm 2.24$ & $4.05^{a} \pm 2.11$ & $4.55^{\mathrm{ab}} \pm 2.19$ \\
\hline$P Y+D C P(50: 50)$ & $3.05^{a} \pm 2.26$ & $4.10^{a} \pm 2.25$ & $3.95^{\mathrm{ab}} \pm 2.56$ & $5.35^{b c} \pm 2.00$ & $5.50^{\mathrm{cd}} \pm 2.57$ & $4.74^{a} \pm 2.11$ & $4.55^{\mathrm{ab}} \pm 2.52$ \\
\hline
\end{tabular}

Values are means \pm standard deviation of 20 panelists. Values with the same superscripts in a row are not significantly $(p<0.05)$ different Key: PY= Plain yoghurt; FCP= Fresh cashew pulp; $\mathrm{DCP}=$ Dried cashew pulp

University of Nigeria Nsukka were involved in the evaluation for colour, taste, aroma, flavour, aftertaste, and overall acceptability. The extent of differences between the yoghurt samples for each sensory attribute was measured on a nine- point Hedonic scale where 9 represents extremely like and 1 represents extremely dislike (Ihekoronye and Ngoddy, 1985).

\section{Data analysis and experimental design}

The experiment was based on completely randomized design. Means separation using one way analysis of variance (ANOVA). was done by the use of Duncan's Multiple Range Test with a statistical software SPSS version (16.0).
Significance was accepted at $p<0.05$ according to Steel and Torrie (1980).

\section{RESULTS AND DISCUSSION}

Sensory scores of yoghurt flavoured with fresh and dried cashew pulp

Table 2 shows the sensory scores of the yoghurt flavoured with fresh and dried cashew pulp, The mean scores of colour ranged from 3.15 for sample PY + DCP $(70: 30)$ to 8.20 for plain yoghurt PY + CP (100:0). Plain yoghurt has the highest score for colour. There was significant difference in the colour of the plain yoghurt and the samples. The value for colour was not significantly $(p<$ $0.05)$ different from the values $(4.20-8.20)$ reported for yoghurt flavoured with solar dried bush mango (Mbaeyi - Nwaoha and Anyanwu, 2010). The value for aroma ranged 4.10 in sample containing $50 \%$ dried cashew and 6.15 in plain yoghurt. There was no significant $(p<0.05)$ difference in plain yoghurt and samples containing $10,20,40$ and $50 \%$ fresh cashew pulp. There was also no significant $(p<0.05)$ difference in plain yoghurt and sample containing $10 \%$ dried cashew pulp.

The values for taste ranged 3.65 in sample PY + DC $(70: 30)$ to 6.55 in plain yoghurt. Plain yoghurt has the highest score (6.55) for taste. However, there was no significant $(p<0.05)$ difference in colour of plain yoghurt and sample containing 10 $\%$ fresh cashew pulp. The result for consistency showed there was $(p<0.05)$ significant difference in the samples. The values ranged 4.05 for sample containing $40 \%$ dried cashew pulp to 6.80 for plain yoghurt. 
Table 3. Proximate composition (\%) of cashew pulp (fresh and dried) flavoured samples

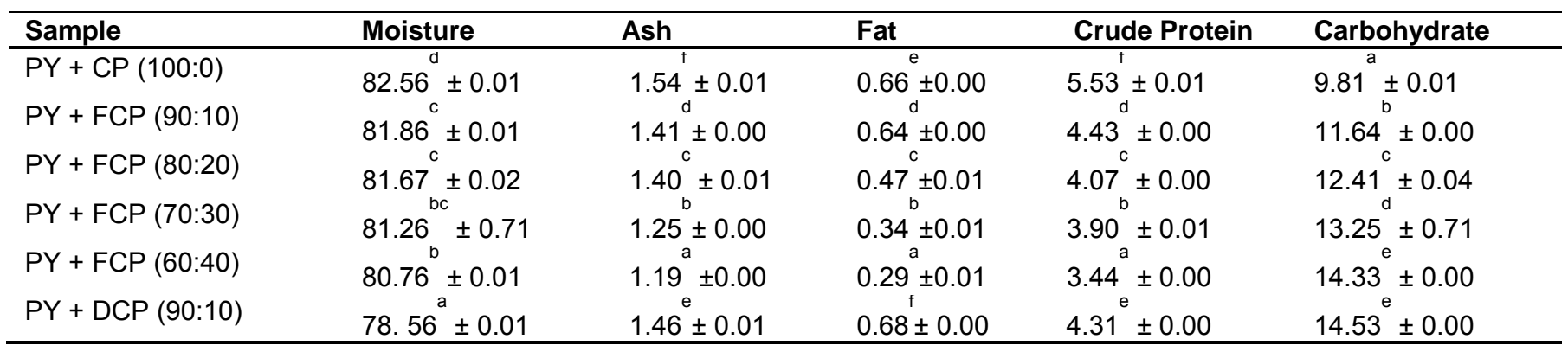

Values are means \pm standard deviation of 20 panelists. Values with the same superscripts in a row are not significantly $(p<0.05)$ different. Key: $\mathrm{PY}=$ Plain yoghurt; $\mathrm{CP}=$ Cashew pulp; $\mathrm{FCP}=$ Fresh cashew pulp; $\mathrm{DCP}=$ Dried cashew pulp.

The preference for consistency of the product reduced in addition of the fresh and dried cashew pulp. This was in agreement that the highly influencing attributes are fat content and addition of milk proteins apart from processing method as reported by Stolz et al. (2011).

The aftertaste scores ranged 4.10 for sample containing $50 \%$ cashew pulp to 5.80 for plain yoghurt. There was no significant $(p<0.05)$ difference in after taste of plain yoghurt and samples containing 10, 30, $40 \%$ FCP and sample 10, 30, 40 and $50 \%$ DC. The mean scores for mouthfeel ranged 4.05 for sample containing $40 \% \mathrm{DC}$ to 6.70 for plain yoghurt [PY + CP (100:0)]. There was no significant $(p>0.05)$ difference in mouthfeel for sample containing $10 \%$ FCP and plain yoghurt. Plain yoghurt had the Highest mean value (6.95) for overall acceptability. However, there was no significant difference $(p<0.05)$ in the overall acceptability for sample containing $10 \%$ FCP and plain yoghurt. The mean score for overall acceptability ranged 4.15 in sample containing $30 \%$ DC to 6.95 for plain yoghurt. High score less than 6.1 were obtained for the plain yoghurt for all the sensory attributes (colour, taste, aroma, aftertaste, consistency and mouthfeel), therefore making it the most preferred sample with an overall acceptability of 6.95 . Sample containing $10 \%$ FCP had the highest mean for overall acceptability (6.40) compared to other flavoured yoghurt samples and the second in terms of preference. Low means were observed in samples containing 20, 30, 40 and $50 \%$ DCP in general acceptability and also in sample containing $50 \%$ DCP. The values below 5.0 in the overall acceptability were discarded because in the Hedonic scale of preference, where scores below 5 represents neither like nor dislike. This result of the sensory evaluation implied that yoghurt flavoured with $10 \%$ FCP could be produced without having a negative impact on the consumer acceptability of product. These quality findings may be useful for yoghurt industries to produce new variety of yoghurts. Plain yoghurt was more highly rated than cashew pulp in all the sensory attributes. This could be attributed to the fact that the panelists were more accustomed to plain yoghurt rather than the cashew pulp flavoured yoghurt that has never been used in yoghurt production prior to this research. The most preferred samples however, were used for further analysis.

\section{Proximate composition of yoghurt flavoured with fresh and dried cashew pulp}

Table 3 shows the proximate composition (\%) of cashew pulp favoured yoghurt samples. The moisture content of the flavoured yoghurt ranged from $78.56-82.56 \%$ (Table $3)$. There was significant $(p<0.05)$ difference in the moisture content of the formulated yoghurt samples and sample PY + CP (100:0). There was a decrease in the moisture content as the cashew pulp was added. Plain yoghurt had the highest moisture $(82.56 \%)$. This decrease in moisture content could be attributed to the solids in the fresh cashew apple pulp and also the dry cashew pulp to mop out free water in the yoghurt. The result concurred with Morvarid et al. (2013) for fruit flavoured yoghurt with moisture content ranging from 71 $-86 \%$.

The carbohydrate content of the flavoured yoghurt samples range from $9.81-14.53 \%$.In the table above, there was significant $(p<0.05)$ difference in the formulated yoghurt samples and the plain yoghurt. Plain yoghurt had the lowest carbohydrate content $(9.81 \%)$. Carbohydrate is the major constituent of milk that is converted to lactic acid during yoghurt (fermentation) production. So, fermentation and conversion of lactose to lactic acid accounted for the low carbohydrate observed in the plain yoghurt. There was an increase in the carbohydrate content with increase in the concentration of the fresh cashew pulp. This could be because cashew apples are rich in reducing sugars (fructose and glucose) as reported by Rabelo et al. (2009). The increase also in the sample PY + DCP $(90: 10)$ could be as a result of the concentration of the carbohydrates during drying. 
Nwaoha et al. 243

Table 4 .Lactic acid bacteria (LAB) and total viable count (TVC) of the formulated yoghurt

\begin{tabular}{llc}
\hline Sample & TVC (cfulml) & LAB (cfulml) \\
\hline PY + CP (100:0) & $2.4 \times 10^{4}$ & $2.7 \times 10^{5}$ \\
PY + FCP (90:10) & $1.9 \times 10^{4}$ & $1.7 \times 10^{5}$ \\
PY + FCP (80:20) & $1.6 \times 10^{4}$ & $2.1 \times 10^{5}$ \\
PY + FCP (70:30) & $2.0 \times 10^{4}$ & $1.5 \times 10^{5}$ \\
PY + FCP (60:40) & $1.3 . \times 10^{4}$ & $1.3 \times 10^{5}$ \\
PY + DCP (90:10) & $1.0 \times 10^{5}$ & $2.0 \times 10^{5}$ \\
\hline
\end{tabular}

$\mathrm{PY}=$ Plain yoghurt; $\mathrm{CP}=$ Cashew pulp; FCP = Fresh cashew pulp; DCP =Dried cashew pulp; $\mathrm{LAB}=$ Lactic acid bacteria; TVC $=$ Total viable count.

The fat content of the formulated yoghurt samples ranged from $0.29-0.68 \%$. The maximum fat content $(0.66 \%)$ was seen in plain yoghurt [sample PY + CP (100:00)] and fat content was found to be decreasing with addition of the fruit pulp (Table 3 ). The fat content differed significantly $(p<0.05)$ in the formulated yoghurt samples and the plain yoghurt. The low fat content of the yoghurt could be attributed to the low oil content of the milk (skimmed milk) which was the major substrate of the yoghurt produced. This corresponded with the other researchers that non-fat yoghurt can be produced but in general, the fat level of every yoghurt depends on oil content of the milk whether skimmed or full cream milk. According to U.S.D.A. (2001), yoghurt with less than 0.5 $\%$ fat content should be labeled, as non - fat yoghurt; those with fat content within the range of $0.5-2.0 \%$ should be labeled low fat yoghurt and those with fat content above $3.25 \%$ should be labeled whole milk yoghurt. Therefore, the formulated yoghurt sample which a fat content ranging $(0.29-0.64 \%)$ could be referred to as low fat yoghurt. This result is however in contrast with the fat content in soursop pulp flavoured yoghurt (2.68 $4.60 \%$ ) as reported by Mbaeyi - Nwaoha and Ekere (2014).

Table 3 showed the crude protein content ranged from $(3.44-5.53 \%)$ with plain yoghurt having the highest crude protein content. the protein content of the flavoured yoghurt decreased with increased level of cashew pulp added. this decrease could be attributed to the lower protein content of cashew apple compared to milk. Morton (1987) reported that cashew apple has a protein content of $0.1-0.16 \%$. Animal milk on the other hand, has a high protein quality as it provides all the amino acids the body needs to function correctly. The protein content of the plain yoghurt agreed with the range (3.4 $5.6 \%$ reported by Janjoj et al. (2006).

Table 3 showed that the ash content ranged from 1.19 $\%$ in sample PY + FCP $(60: 40)$ to $1.54 \%$ in sample PY + CP (100:0). The result showed a decrease in the ash content of the formulated yoghurt. There was an increase in the ash content for sample DCP $(90: 10)$ compared to the samples flavoured with fresh cashew pulp. This could be as a result of the dying. The ash content was somewhat lower than that of plain yoghurt but differences in ash content between samples was not significant $(p<$ $0.05)$. This was in agreement with the ash content (1.03 $1.56 \%$ ) reported by El-Batawy (2014) for impact of mango and pomegrante peels supplementation on quality characteristics of yoghurt. According to McClements (2003), ash could be the residue after water and organic matter have been removed by heating in the presence of oxidizing agents, which provides a measure of the total amount of minerals present in a food. Milk however, is rich in minerals, some of which are not found to be very low in cashew apple. This therefore, justified the decrease in ash content with the addition of cashew pulp.

\section{Microbial count (cfu/ml) of yoghurt flavoured with cashew apple pulp (fresh and dried)}

Table 4 shows the microbial population of the formulated yoghurt. The samples showed a lactic bacteria count of $1.3 \times 10^{5}-2.7 \times 10^{5}$ (cfu/ml) The LAB count was also observed to decrease with increase in the cashew fruit concentration. This could be as a result of the decrease in the milk content which contains lactose which acts as a substrate for growth and multiplication of the LAB. This decrease could also be responsible for the increase in $\mathrm{pH}$ observed. According to Kubu et al. (1993), it was reported that cashew apple has anti-bacterial properties. This could have affected the microorganisms thereby leading to reduction in their level with increased addition of cashew pulp.

The TVC of the samples ranged $1.3 \times 10^{4}$ in sample PY $+\operatorname{FCP}(60: 40)$ to $1.0 \times 10^{5}$ in sample containing $10 \%$ DCP. There was a decrease in the TVC as the cashew pulp was added with the exception of the sample PY + DCP (90:10). This increase in the TVC of the formulated dried cashew pulp yoghurt could be because of the concentration of nutrients during drying, since drying concentrates nutrients thus, led to the increase in the multiplication of the microorganisms.

\section{Micro - nutrient composition of cashew apple pulp flavoured yoghurt (fresh and dried)}

The selected vitamins $C$ and mineral composition of the flavoured samples are shown in Table 5. 
Table 5. Vitamins $\mathrm{C}$ and mineral composition of cashew flavoured yoghurt

\begin{tabular}{|c|c|c|c|}
\hline Sample & Vitamin C & Potassium & Calcium \\
\hline & $(\mathrm{mg} / 100 \mathrm{~g})$ & $(\mathrm{mg} / 100 \mathrm{~g})$ & $(\mathrm{mg} / 100 \mathrm{~g})$ \\
\hline$P Y+C P(100: 0) \quad 16.45^{\circ}$ & \pm 0.01 & $29.43^{f} \pm 0.01$ & $44.43^{f} \pm 0.00$ \\
\hline$P Y+F C P(90: 10) 20.52^{C}$ & \pm 0.01 & $29.24^{e} \pm 0.01$ & $38.43^{e} \pm 0.00$ \\
\hline$P Y+F C P(80: 20) 24.88^{d}$ & \pm 0.00 & $27.37^{c} \pm 0.00$ & $36.14^{c} \pm 0.00$ \\
\hline$P Y+F C P(70: 30) 26.30^{e}$ & \pm 0.01 & $26.11^{\mathrm{b}} \pm 0.00$ & $35.62^{b} \pm 0.01$ \\
\hline$P Y+F C P(60: 40) 28.60^{f}$ & \pm 0.00 & $25.63^{\mathrm{a}} \pm 0.02$ & $33.58^{a} \pm 0.02$ \\
\hline$P Y+D C P(90: 10)$ & $16.84^{\mathrm{b}}$ & $29.17^{d} \pm 0.01$ & $37.89^{d} \pm 0.00$ \\
\hline
\end{tabular}

Values are mean \pm standard deviation of duplicate readings. Means on the same column with different superscripts are significantly $(p<0.05)$ different.

Table 6. Physico-chemical properties of cashew flavoured yoghurt samples

\begin{tabular}{|c|c|c|}
\hline Sample & Titrable Acidity & Total Solids (\%) \\
\hline $\begin{array}{l}P Y+C P(100: 0) \quad 4.65^{b} \pm 0.07 \\
P Y+F C P(90: 10) 4.50^{a} \pm 0.00 \\
P Y+F C P(80: 20) 4.65^{b} \pm 0.71 \\
P Y+F C P(70: 30) 4.65^{b} \pm 0.71 \\
P Y+F C P(60: 40) 4.40^{a} \pm 0.00 \\
P Y+D C P(90: 10) 5.45^{c} \pm 0.14\end{array}$ & $\begin{array}{l}0.55^{\mathrm{e}} \pm 0.01 \\
0.42^{\mathrm{b}} \pm 0.00 \\
0.42^{\mathrm{b}} \pm 0.00 \\
0.47^{\mathrm{c}} \pm 0.00 \\
0.52^{\mathrm{d}} \pm 0.00 \\
0.36^{\mathrm{a}} \pm 0.00\end{array}$ & $\begin{array}{l}18.71^{\mathrm{a}} \pm 0.01 \\
19.43^{\mathrm{b}} \pm 0.00 \\
20.82^{\mathrm{d}} \pm 0.01 \\
21.21^{\mathrm{e}} \pm 0.01 \\
22.19^{\mathrm{f}} \pm 0.01 \\
19.74^{\mathrm{c}} \pm 0.01\end{array}$ \\
\hline
\end{tabular}

Values are mean \pm standard deviation of duplicate readings. Values on the same column with different superscripts are significantly $(p<0.05)$ different

Key: $\mathrm{PY}=$ Plain yoghurt; $\mathrm{CP}=$ Cashew pulp; FCP $=$ Fresh cashew pulp; $\mathrm{DCP}=$ Dried cashew pulp

The vitamin $\mathrm{C}$ content of the formulated yoghurt ranged $16.45-28.60 \mathrm{mg} / 100 \mathrm{~g}$. Table 5 showed that vitamin C content of the flavoured yoghurt increased with increase concentration of cashew apple. Cashew is a valuable source of vitamins. According to Morton (1987), Cashew apple has a vitamin C content of 142 - $372 \mathrm{mg}$. Cashew apple contain five times as much vitamin $\mathrm{c}$ as citrus juice (Akinwale. 2000) and ten times as pineapple juice (Ohler, 1998) as well as other health benefits which cannot be over emphasized such as anti-bacterial, antioxidant and mutagenic effect. This implied that by incorporating cashew pulp into yoghurt (which is more widely consumed), the benefits would be easily accessible. The increase in the blending ratios, increased the vitamin C content of the yoghurt.

The potassium content of the formulated yoghurt samples ranged from $25.63-29.43 \mathrm{mg} / 100 \mathrm{~g}$. There was significant $(p<0.05)$ difference in the samples. The potassium content of the plain yoghurt [PY + CP (100:0)] decreased with increased concentration of cashew pulp. Plain yoghurt had the highest potassium content of 29.43 $\mathrm{mg} / 100 \mathrm{~g}$. This decrease could be because cashew apple has a lower potassium content than milk. Yoghurt has a potassium content of $380 \mathrm{mg} / 100 \mathrm{~g}$ (Anon, 2012) while cashew apple according to Catherine (2012), cashew apple has a potassium content of $124 \mathrm{mg} / 100 \mathrm{~g}$. This justifies the low loss in potassium content with increased concentration of cashew pulp added.
Table $6 \mathrm{~s}$ showed that the calcium content of the samples ranged between 33.57 in sample PY + FCP $(60: 40)$ to $44.43 \mathrm{mg} / 100 \mathrm{~g}$ in sample PY + CP (100:0). Plain yoghurt has the highest calcium content of 44.43 $\mathrm{mg} / 100 \mathrm{~g}$. There was no significant $(p<0.05)$ differences between the samples. The lower level of calcium in the samples containing cashew pulp could be attributed to the substitution of milk with cashew pulp which as a lower calcium content. The result justifies the assertion of Gray (2007) that yoghurt is a very good source of essential minerals needed for human metabolism or functionality of cells. While according to Morton (1987) cashew apple has a calcium content of $0.9-5.4 \mathrm{mg}$.

\section{Physico-chemical properties of cashew apple pulp flavoured yoghurt (fresh and dried)}

Table 6 shows some selected physico-chemical properties of flavoured with fresh and dried cashew pulp.

Table 6 showed that the $\mathrm{pH}$ of the flavoured samples ranged 4.40 for sample PY + FCP $(60: 40)$ for sample to 5.45 in sample PY + DCP (90:10). The addition of fresh cashew pulp slightly lowered the acidity of the yoghurts in sample containing 10 and $40 \%$ of fresh cashew pulp. This decrease could be due to the low acidity of cashew as reported by Marc et al. (2012) for $\mathrm{pH}$ of cashew juice which ranged $4.37-4.43$. There was no significant $(p<$ 0.05 ) difference in $\mathrm{pH}$ of the samples containing 20 and 
$30 \%$ fresh cashew pulp and plain yoghurt. However, there was an increase in $\mathrm{pH}$ of the sample containing 10 $\%$ dried cashew pulp. These results relatively corresponds to Rodrigues et al. (2010) who concluded that $\mathrm{pH}$ of yoghurt is $4.30-5.08$. The $\mathrm{pH}$ of 4.40 in sample containing $40 \%$ fresh cashew pulp and 4.65 in plain yoghurt, samples containing 20 and $30 \%$ fresh cashew pulp were in accordance with FDA (2009) specifications (of 4.6 or lower) for the $\mathrm{pH}$ of yoghurt. The increase in acidity of the flavoured yoghurt samples could probably be attributed to the fact that the cashew apple has high acidity. This result is also in accordance with the report given by Dlamini et al. (2009) whose results indicated that the use of indigenous fruits resulted in a slight increase in the acidity of yoghurts.

The values obtained $(0.38-0.55)$ in this study for titrable acidity is similar to the values $(0.22-0.50)$ reported by Joseph and Joy (2011). However, this is generally below the standard which is $0.7 \%$ (FDA, 2009). A direct relationship was observed between $\mathrm{pH}$ and titrable acidity as has been previously reported (Dublin Green and Ibe, 2005).

The total solids of the flavoured samples ranged from $18.71-22.19 \%$. Total solids increased with increase in the concentration of the cashew pulp in the yoghurt. sample PY + CP (100:0) had the lowest total solids content $(18.71 \%)$ while the sample PY + FCP $(60: 40)$ had the highest total solids content $(22.19 \%)$. High total solids might also be the cause of increased acidity in the yoghurt samples containing fresh cashew pulp, which affects the activity of the lactic acid bacteria.

\section{CONCLUSION}

From the results obtained, the nutritional quality of the plain yoghurt was improved by the addition of cashew apple especially in terms of vitamin C. This implied that the therapeutic potency of yoghurt could be improved because the consumption of foods with high vitamin $\mathrm{C}$ can aid in combating deficiency disease like scurvy. The sensory attributes (colour, taste, aroma, mouthfeel consistency and overall acceptability) evaluated revealed appreciable degrees of acceptance by the panelists thereby increasing varieties of yoghurt in the market. This results also showed that the addition of cashew pulp had a positive effect on the proximate of the formulated product. Fresh cashew pulp with the ratio of 90:10 was the most preferred among the formulated yoghurt samples formulated with an overall acceptability of 6.40.

\section{REFERENCES}

Adegoke GO, Ese EN, Akanni AO (1992). Effects of heat, processing time and $\mathrm{pH}$ on the microflora, aflatoxin content and storability of wara- A white cheese, Die-Nahrung 36: 259-264.

Akinwale TO (2000). Cashew apple juice: Its use in fortifying the nutritional quality of some tropical fruits. European. Food Resour. Technol. 211: 205-207.

Anon (2012). Yoghurt varieties. www.aboutyoghurt.com. Accessed $15^{\text {th }}$ July, 2015.

AOAC (2010). Official methods of Analysis of Association of Analytical Chemists, $18^{\text {th }}$ ed., published by AOAC International, Gaithersburg, Maryland, USA.

Blanc B (1981). Biochemical aspects of human milk comparison with bovine milk. World Rev. Nutri. Diet. 36: 1-8.

Boulioux P, Koletzko B, Guarner F, Braesco V (2003). The intestine and its micro flora are partners for the protection of the host: Report in Dannone symposium the intelligent intestine. J. Clini. Nutri.78: 175183.

Catherine R (2012). All about cashews apple in India. http://www.wikipedia.com. Accessed $24^{\text {th }}$ July, 2015.

Dublin-Green M, Ibe SN (2005). Quality evaluation of yoghurts produced commercially in Lagos, Nigeria. Afri. J. Appl. Zool. Environ. Biol. 7:78-82.

Dlamini AM, Mamba R, Silaula, SM (2009). Attributes and consumer acceptance of yoghurt flavoured with non-cultivated indigenous food. Agricultural Nutritional Development, 9 (1): 636 - 657.

El-Bataway OI, Ashoush IJ, Melanna N (2014). Impact of mango and pomegranate peels on quality characteristics of yoghurt with or without protein. World J. Dairy and Food Science, 9(1):57-65.

FDA (2009). Milk and cream products and yoghurt Products. Food and Drug Administration. Federal Register, 74: 2448.

Gray C (2007). Yoghurt and your health. Star Base Publication, Washington. pp. 6 - 8 .

Harrigan WE McCance ME (1976). Basic methods. In: Laboratory Methods in Foods and Dairy Microbiology. Academic press, London. pp. 3-16.

Ihekoronye Al (1999). Manual of small-Scale Food Processing. Macmillan Publishers Ltd, London. pp. 108-212.

Ihekoronye Al, Ngoddy PO (1985). Integrated Food Science and Technology for the Tropics. Macmillan Publishers Ltd, London. pp. 368-369.

Janhoj E, Charlotte B, Michael B (2006). Sensory and rheological characterization of low fat stirred yoghurt. J. Tex. Stud. 37:276-299

Joseph AO, Joy EO (2011). Physico-chemical and sensory evaluation of market yoghurt in Nigeria. Pak. J. Nutri. 10(10): 914-918.

Kirk RS, Sawyer R (1991). Pearsons' Composition and Analysis of Foods, $8^{\text {th }}$ ed., Longman Group Ltd, London. pp. 125-130.

Kubu I, Ochi M, Vieira PC Komatsu S (1993). Antitumor agent from the cashew (Anacardium occidentale) apple juice. J. Agric. Food Chem. 41:1012-1015

Marc A, Fabrice AT, Mory G, Kouakou NL, N'Guessan GA (2012). Physico chemical characterization of cashew apple juice (Anacardium occidentale) from Yamoussoukro (Cote D'Ivore) Romanian Food Biotechnology, 11: 32 - 43.

Mbaeyi-Nwaoha IE, Ekere KS (2010). Production and evaluation of flavoured yoghurt from graded levels of soursop (Anona muricata) pulp. Innovare J. Food Sci. 2(1): 14 - 21.

McClements DJ (2003). Analysis of food products (Food Science 581). www.people.umass.edu/581Asharidminerals. Accessed $27^{\text {th }}$ June 2015.

Moravarid V, Leila H, Azadi E (2013). Effect on different concentration of fruit additives on some physic-chemical properties of yoghurt during storage. Annals Biol. Res. 4(4):244 - 249.

Morton J (1987). Cashew apple. In: Fruits of Warm Climates. Julia F. Morton Publishers., Miami, Florida. pp. 239-240.

Oduwole OO, Akinwale TO Olubamiwa O (2001). Economic evaluation of a locally fabricat-ed extraction machine for a cottage cashew juice factory. J. Food Technol. Afri. 6 (1): 1-20.

Ogunjobi, M. A .K. and Ogunwolu, S. O. (2010). Development and Physiochemical evaluation of wine produced from cashew apple powder. J. Food Technol. 8(1):18-23.

Ohler JG (1998). Cashew communication 71. Royal Tropical Institute. Amsterdam. pp. 260- 268. 
Osborne DR, Voogt R (1978). The Analysis of Nutrients in Foods. Academic Press, New York, $6^{\text {th }}$ ed. pp. $251-255$.

Oyenuga, VA (1968). Nigerian Foods and Feeding Stuff: Their Chemistry and Nutritive value. University Press, Ibadan, Nigeria, pp. $9-16$.

Pearson, D (1976). The Chemical Analysis of Foods $7^{\text {th }}$ Ed. ChurchHill Livingstone Publication, London. pp. 383 - 387.

Prescott WJ, Harley JP, Klein OA (2005). Microbial Nutrition - Types of media. In: Microbiology, $6^{\text {th }}$ Ed., McGraw Hill Publishers New York. pp. 95 - 105.

Rabelo MC, Fontes COMM, Rodrigues S (2009). Enzyme synthesis of oligosaccharides using cashew apple juice as substrate. Biores. Technol. 10(23): 5414-5580.

Roudrigues LA, Ortolani MBT, Nero LAC (2010). Microbial quality of yoghurt commercialized in Vicosa, Minas Gerais, Braz. Afri J. Microbiol. Res. 4(3):210- 213.

Routray W, Mishra, HN (2011). Scientific and technical aspects of yoghurt aroma and taste: A review. Comprehensive Reviews in Food Science and Food Safety. 10: 208-210.
Steel, RD, Torrie JH (1980). Principles of Statistics. McGraw-Hill, New York. pp. 168-183.

Stolz H, Espig F, Kretzschmar U (2011). Facts sheets in all the tasted products in the approprate language. Research Institute of Organic Agriculture (FiBL), Frick, Switzerland.www.fibl.org. Accessed on $10^{\text {th }}$ June 2015.

Tamine AY Robbinson RK (2007). Yoghurt Science and Technology, $3^{\text {rd }}$ edition. Woodhead Publishing Ltd. USA. pp. 791-798.

Tull A (1996). Food and Nutrition, Oxford University Press, London. pp. 109-111.

USDA (2001). USDA Specifications for yogurt, nonfat Yogurt and low fat yoghurt. Dairy Programs. Agricultural Marketing Services. United States Department of Agriculture, Washington, DC. 